\title{
Evaluation of Moringa oleifera, Zingiber officinale (Ginger), Chromolena odorata Plants Extract as Seed Borne Of Cowpea
}

\author{
${ }^{1 *}$ Abiamere, C.O., ${ }^{2}$ Nweke, F.N., ${ }^{1}$ Ogbadu, L.J., ${ }^{1}$ Onyia, O.C. and ${ }^{1}$ John, C.O. \\ ${ }^{1}$ National Biotechnology Development Agency (NABDA) Abuja, Nigeria. \\ ${ }^{2}$ Department of Biology/Microbiology/Biotechnology, Federal University Ndufu Alike Ikwo, Ebonyi State, \\ Nigeria.
}

\begin{abstract}
Cowpea is an extremely resilient crop and is cultivated under extreme agricultural conditions. The high protein content of the seeds as well as their special characteristics as legume crops continue to make future expansion of cowpea cultivation highly desirable in Nigeria. It is mostly an important source of protein and high quality legumes hay for livestock feed. The efficiency of several leaf extracts applied as seed treatment in the control of major seed-borne fungi of cowpea and their effects on seed germination were evaluated using the standard blotter method. Cowpea seeds have natural incidence of Aspergillus flavus (55.3\%), Aspergillus niger (63.0\%), Aspergillus terreus (20.0\%), Fusarium moniliforme (35.3\%), Macrophomina phaseolina (10.5\%), Botryodiphodia theobromae (5.8\%), Penicillin sp. (21.0\%) and Rhizopus stolonifer $(25.8 \%)$. The results showed that all the leaf extracts reduced the incidence of the fungi and increased seed germination percentage. Inhibition of fungal incidence was highest in Chromolena odorata extracts and the lowest in extracts from ginger. Phytotoxic effects on cowpea were not observed. The result of this work showed that plant extracts are effective in controlling seed-borne fungi of cowpea seeds with increase in germination. The extracts have some fungicidal properties that inhibit the seed-borne fungi.
\end{abstract}

Key words: Plant extract, cowpea and seed borne

\section{Introduction}

Cowpea Vigna unguicualata (L) Walp originated from African and is commonly cultivated in the semi-arid and forest margin tropic and sub-tropics where it is well adapted and probably the most popular grain legume crop.In Nigeria, most varieties such as Vigna unguiculata var., unguiculata V., sinensis and Vigna unguiculata var. sequipedelis are found in Kano, Sokoto, Kaduna, Bauchi, Bornu and Niger states in the North whereas in the south, they are cultivated in Oyo, Osun and Ondo states (Purseglove, 1987). Cowpea is an extremely resilient crop and is cultivated under some of the most extreme Agricultural conditions in the world. Some of the varieties grown in the Sahel and Sahara are drought and heat tolerant (Singh et al.,1 999).

The high protein content of the seeds as well as their special characteristics as legume crops continue to make future expansion of cowpea cultivation highly desirable. Previous research has shown that cowpea plant is capable of producing a large number of flowers on each inflorescence (Emebiri and Obisesan, 1988). It is mostly an important source of protein and high quality legumes hay for livestock feed.

Cowpea ( Vigna unguiculata) is cultivated in Nigeria as a pulse for human consumption. They may be processed into a paste and used as Akara (fried bean cake), moi moi (steamed beans paste) or a variety of other dishes. The seeds may be used as hay, silage, pasture, soil cover and green manure (Verdcourt, 1970).

Cowpea seed contains a lot of nutritious component and vitamins in the human diet, as well as a nutritious livestock feed. The seeds are sometimes used as a coffee substitute. The protein is rich in amino acids, lysine and tryptophan compared to cereal grains (Verdcourt, 1970).

Cowpea can be at all stages of growth as vegetable crop. The tender green leaves are important food source in African and prepared as a pot herb. In some countries such as India, immature pods and peas are used as vegetables while several snacks and main meal dishes are prepared from the grains. The spreading indeterminate or semi-determinate bushy growth of cowpea provides ground cover, thus suppressing weeds and providing some protection against soil erosions (Verdcourt, 1970).

In addition, some cowpea varieties are suicidal. Germination of the seeds of Striga hermothica, a parasite plant, which may infest the cereals, often with devastating effects. Another important feature of the cowpea is that it fixes atmospheric nitrogen through symbiosis with nodules bacteria, Bradyrhyzobuim $s p$, (Singh et al 1999). Cowpea has been reported to show high susceptibility to pests and disease (Purseglove, 1987). Kay (1979). Messiaen and Lafon (1970), Smart (1976), Kranz et al (1977) also reported many seedborne pathogens such as Tracheiphilum, C rolfsii, M. phaseolina. These pathogens cause a lot of damage to crops and are also responsible for the deterioration of seed quality, seed-rots, and seedling mortality and stem rot diseases. 
Seed-borne diseases are often the cause of the death of seed in storage or in the soil after planting. If the diseased seeds germinate, they may result in weak or death of seedling and cause reduction in quality and quantity of the crops.

The major disease of cereals and legume that have caused disastrous crop losses leading to food shortage and famine all over the world are also known to be seed-borne, Richardson (1990). Infected seeds act as a media for the survival of these fungi and their spread to disease-free area (Agarwal, 1981). The disease attacks all aerial parts of the plant but cause most damage on the pods. Cowpea scrab and pod spot is a disease caused by Cladosporium vignae. It is usually severe and results in a partial or complete loss of more susceptible varieties in some seasons, the fungus survives on the seed coat or in the cotyledons until planting time. Cowpea wilt is caused by two Fusarium Sp namely Fusarium oxysporium and Fusarium tracheiphilum (Kay, 1979, Dixon, 1981, Messiaen and Lafon 1970). The symptoms do not appear until the plants are about six weeks old. Growth is stunted, chlorosis, dropping, premature shedding or wilting of leaves and veinal neurosis often occur and the plant finally dies. Seedling blight, stem, collar rot and root rot of the cowpea is caused by Corticum rolfsii. The disease is widely distributed in warm climates and attacks a wide range of plant (Kay 1979, Kranz et al 1977). The pathogen includes the sclerotia and pycnidia, which occur on the surface or under the seed coat. The symptoms vary and include rapid death of then young succulent plants. During warm, moist conditions, the coarse, white mycelium of fungus makes characteristic fan-shaped pattern of growth on the stem at the soil line.

In recent years, attention has been given to the treatment of seed with non-chemical to protect them against seed-borne pathogens. Plant extracts have played a major role in the inhibition of seed-borne pathogens and increasing seed germination. Shah et al, 1992 reported that Argemone mexicana seed extracts was effective in eliminating most of the seed-borne fungi of cowpea but against Alternaria alternata, Curvularia lunata, mucor sp., and m. phaseolina. Nwachukwu and Umechuruba (2001) reported that leaf extracts of Ocimum basilicum, Vernonia amygdalina, Cymbopogen citratus and Azadirachta indica significantly reduced the mycelia growth of $F$ Moniliforme, A niger, A flavus and $B$ theobromac and increased seed germination and emergence of African yam bean seeds. Leaf extracts of Delomic regia, Pongamia globra and Acacia nilotica, inhibited spore germination, mycelia growth and spore production of A. helianthi, $M$. phaseolina and $F$ solani from Sunflower seeds (Thiribhuvanamala and Narasinihan 1998). Parimelazhagan and Francis, (1999) reported the reduction in the radial growth of $C$. lunata associated with rice seeds when treated with leaf extracts of Clerodendrum viscosum which also increased germination and root and shoot length of rice.

In view of this; investigation was carried out on the effect of different concentration of plant extracts on seed-borne fungi of cowpea seeds and on seed germination. The objectives of this study was to isolate and identify the different types of fungi associated with cowpea seeds and determine the effects of different concentrations of some plant leaf extracts on the germination of cowpea seeds and the incidence of seed-borne fungi.

\subsection{Materials}

\section{Materials and Methods}

Materials used for the study include; autoclave, incubator, blender, $70 \%$ ethanol, $1 \%$ sodium hypochlorite and glassware All the glassware and reagents were sterilized using autoclaved for 15 minutes while working surface and incubator were also sterilized with $70 \%$ ethanol.

\subsection{Source of Cowpea Seeds and Plant Materials}

The Cowpea ( Vigna unguiculata) L. walp seeds were obtained from Mile 1 Market, Port Harcourt in Rivers State. The plant leaves such as (Moringa oleifera (Drum stick) was collected at G.R.A, Ginger (Zingiber officinale) was bought at fruit and vegetable market at Kaduna Street in Port Harcourt, and "Awolowo leaf' (Chromolena odorata) was collected at the back of Offirima in the University of Port Harcourt. They were collected in sterile polythene bags and brought to the laboratory.

\subsection{Detection of Seed-Borne Fungi}

The standard blotter method as described by International Seed Testing Association (ISTA, 1966) was used for the detection of the seed-borne fungi associated with all the samples. Three layers of blotters were soaked in sterilized distilled water and placed in sterile glass petri dished of $9 \mathrm{~cm}$ diameter. Ten seeds were used for each sample pretreated with $1 \%$ sodium hypochlorite (common bleach) solution for five minutes before plating without pre-treatment. The plated seed was incubated for seven days. At the end of the incubation period, the seeds were examined under Stereobinocular microscope (6-50x) for fungal growth. 


\subsection{Identification of Seed-Borne Fungi}

Observation on different seed-borne were made under stereoscopic microscope (50x magnification) after seven days of incubation. Detailed colony characters such as type of mycelial growth, colour of mycelium, characters of sporodochia or pinnotes and other general characters of the spore bearing organs in terms of the shape, size and colour were recorded. Slides were prepared from colonies on the seeds and studied under the compound microscope to record conidal characters in terms of their shape and size. The isolates were brought into spore; isolates were studies for different growth characters and identification following the system of taxonomy and nomenclature proposed by Barnett and Hunter (1972).

\subsection{Effect of Leaf Extracts on Incidence of Seed-Borne Fungi and Seed Germination of Cowpea Seeds Extraction of Leaf Extracts}

The fresh leaves of Moringa oleifera, Zingiber officinale (Ginger), Chromolena odorata, were carefully washed separately under tap water and cut into tiny pieces. Aqueous extract was prepared as follows: $1 \mathrm{~kg}$ whole leaves of each plant was blended separately in one litre of distilled water in a blender and sieved through a Bucher Funnel also to remove debris. The following concentrations were obtained using distilled water: crude $100 \%, 80 \%, 60 \% 40 \%$ and $20 \%$. The cowpea seeds were soaked in different concentrations of leaf extracts separately in a beaker for 5 minutes. At the end of the 5 minutes pre-soaking period, the seeds were plated on three layers of blotter paper moisted with distilled water. Ten seeds were plated in each $9 \mathrm{~cm}-$ diameter petri dish and incubated for 7 days at $22+2 \mathrm{oc}$. At the end of the incubation period, the seeds were examined for fungal incidence under a stereobinocular microscope. Percentage seed germination was recorded.

\section{Results}

(a) Seed-Borne Fungi Isolates Associated with Cowpea Seeds

Table 1 Mean Percentage Incidence of Seed-Borne Fungi of Associate with Cowpea Seeds

\section{$\%$ incidence of fungi \\ Pretreated}

\section{Seed-borne fungi isolated} Untreated

\section{A. Flavus}

\section{$\%$ incidence of fungi}
A. Niger
A. Terreus
F. moniliforme
M. macrophomina
B.
Theobromae
Penicillin sp
R. stolonifer
$\%$ germination

55.3

63.0

20.0

35.3

10.5

5.8

21.0

Seed-borne fungi isolated from cowpea seed pretreated with $1 \%$ sodium hypochlorite and untreated seeds and percentage seed germination are shown in Table 1 . The most commonly isolated fungi from both pretreated and untreated seeds were Aspergillus flavus, A niger, A. terreus, F. moniliforime, M. macrophonina, penicillin sp, Stolonifer and B. theobromae. Aspergillus niger gave the highest percentage incidence of all the fungi in both pretreated and untreated seeds followed by A. flavus and $F$. moniliforme. Generally pretreated with $1 \%$ sodium hypochlorite reduced all the seed borne fungi and gave complete reduction of $B$. theobromae (Table 1).

Table 2 Effects of Different Concentrations of Leaf Extract of Moringa oleifera on Incidence of Seed-Borne Fungi and Seed Germination

\begin{tabular}{lllllll}
$\begin{array}{c}\text { Incidence of Fungi } \\
\text { Fungi isolated }\end{array}$ & $\begin{array}{l}\text { Control } \\
\text { (Distilled water) }\end{array}$ & $\mathbf{2 0}$ & $\mathbf{4 0}$ & $\mathbf{6 0}$ & $\mathbf{8 0}$ & $\mathbf{1 0 0}$ \\
& 54.8 & 55.0 & 48.0 & 20.5 & 15.0 & 4.0 \\
A. Flavus & 62.5 & 60.8 & 60.0 & 20.3 & 13.3 & 3.5 \\
A. Niger & 21.0 & 20.8 & 18.0 & 8.5 & 3.5 & 1.5 \\
A. Terre us & 34.8 & 35.0 & 30.5 & 18.0 & 3.0 & - \\
F. moniliforme & 10.0 & 11.0 & 9.5 & 5.3 & - & - \\
M. phaseolina & 4.8 & 1.0 & - & - & - \\
B. Theobromae & 4.5 & 19.5 & 15.5 & - & - & - \\
Penicillin sp & 20.5 & 25.0 & 20.0 & - & - & - \\
R. stolonifer & 26.5 & $56 \%$ & $60 \%$ & $70 \%$ & $70 \%$ & $94 \%$ \\
\% germination & $54 \%$ & & & & & \\
\hline
\end{tabular}


(b) Effects of Leaf Extracts of Moringa oleifera on Incidence of Seed-Borne Fungi of Cowpea and Seed Germination

The result of effects of different concentrations of Moringa leaf extract on seed-borne fungi and seed germination show that the higher extract concentrations gave very high reduction of incidence of all the fungi (Table 2). The crude extracts (100\%) followed by $80 \%$ and $60 \%$ gave the highest reduction of fungal incidence, respectively. These concentrations gave complete reduction in B theobromae, $R$. stolonifer and Penicillium sp. The crude extract gave highest percentage germination (94\%) compared with control (54\%).

Table 3 Effects of Different Concentrations of Ginger Extracts on Seed-Borne Fungi of Cowpea and on Seed Germination

\begin{tabular}{|c|c|c|c|c|c|c|}
\hline \multirow[b]{2}{*}{ Fungi isolated } & \multicolumn{5}{|c|}{ \% Incidence of Fungi leaf extract concentrations } & \multirow[b]{2}{*}{100} \\
\hline & Control water) & (Distilled 20 & 40 & 60 & 80 & \\
\hline A. Flavus & 49.5 & 50.0 & 51.3 & 48.0 & 30.3 & 16.0 \\
\hline A. Niger & 62.0 & 61.0 & 58.0 & 55.0 & 29.8 & 13.0 \\
\hline A. Terreus & 21.0 & 20.8 & 22.3 & 18.0 & 10.5 & 5.5 \\
\hline F. moniliforme & 28.5 & 23.3 & 20.0 & 15.0 & 10.0 & 1.5 \\
\hline M. phaseolina & 12.5 & 10.0 & 11.5 & 8.5 & 5.0 & - \\
\hline B. Theobromae & 8.3 & 9.5 & 9.0 & 7.0 & 3.8 & - \\
\hline Penicillin sp & 20.8 & 22.5 & 21.5 & 18.0 & 12.5 & - \\
\hline R. stolonifer & 20.5 & 18.5 & 19.0 & 15.3 & 10.0 & - \\
\hline$\%$ germination & 58 & 60 & 61 & 60 & 63 & 85 \\
\hline
\end{tabular}

(c) Effects of Different Concentrations of Ginger Zingiber officinale Extract on Seed Germination and Incidence of Seed-Borne Fungi of Cowpea Seeds

The results showed that only higher concentrations $(60,80$, and $100 \%)$ of ginger were effective in reducing the incidence of seed-borne fungi and in improving seed germination (Table 3). The lower concentrations (20 and $40 \%$ ) of ginger extracts were as good as the control (Table 3 ). The crude extracts (100\%) completely eliminated M. phaseolina, B. theobromae, Penicillium sp and R. stolonifer. This concentration also gave the highest percentage seed germination.

Table 4 Effects of Different Concentrations of Leaf Extracts of Chromolena odorata on Seed-Borne Fungi and

Seed Germination of Cowpea Seeds

\begin{tabular}{|c|c|c|c|c|c|c|}
\hline \multicolumn{7}{|c|}{ \% Incidence seeds borne fungi leaf extract concentrations } \\
\hline Fungi isolated & \multicolumn{6}{|c|}{ (Distilled water) } \\
\hline A. Flavus & 56.5 & 30.0 & 23.3 & 10.5 & 8.0 & 5.0 \\
\hline A. Niger & 65.8 & 31.0 & 20.8 & 14.0 & 5.0 & 4.8 \\
\hline A. Terreus & 28.0 & 18.0 & 10.3 & 5.0 & - & - \\
\hline F. moniliforme & 36.0 & 20.3 & 15.0 & 6.3 & 6.0 & 2.5 \\
\hline M. phaseolina & 11.3 & 10.0 & 5.3 & - & - & - \\
\hline B. Theobromae & 5.5 & 3.0 & - & - & - & - \\
\hline Penicillin sp & 20.0 & 11.8 & 5.0 & - & - & - \\
\hline R. stolonifer & 30.0 & 21.3 & 15.0 & - & - & - \\
\hline$\%$ seed germination & 48 & 60 & 85 & 100 & 100 & 100 \\
\hline
\end{tabular}

(d) Effects of Different Concentrations of Leaf Extracts of Chromolena odorata on Seed-Borne Fungi and Seed Germination of Cowpea Seeds

The effects of leaf extracts of Chromolena odorata on seed-borne fungi on seed germination on cowpea seeds are recorded in Table 4. Results showed that all leaf extract concentrations tested were effective in controlling seed-borne fungi and increased seed germination better than the control. The highest percentage seed germination $(100 \%)$ was recorded by 60,80 and $100 \%$ leaf extract. Furthermore, these higher concentrations completely eliminated M. Phaseolina, B. theobromae Penicillium sp, R. Stolonifer from the seeds.

\section{Discussion}

The efficacy of different leaf extracts Moringa oleifera, Zingiber officinale and Chromolena odorata against major seed-borne fungi of cowpea seeds was tested by treating the seed with different plant extracts. The 
result showed that all the leaf extracts reduced the incidence of the fungi and increased seed germination percentage. Inhibition of fungal incidence was highest in Chromolena extracts and the lowest in extracts from ginger. This result agrees with that of Nwachukwu and Umechuruba (2001) that reported a significant reduction of fungal incidence of African yam bean seeds in extracts of neem, basil, pawpaw, bitter leaf and lemon grass. Nidiry (1999) also obtained a similar result with tomato seed extract, which reduced the mycelia growth of Colletrotichum gleosporioides and spore germination of Cladosporum cucumerinum. Shah et al (1992) in their studies reported that Argemlone mexicana seed extracts was effective in eliminating most of the seed-borne fungi of cowpea but not against Alternarian alternata, Curvularia lunata, Mucor sp. and Macrophomina phaseolina.

All the plant extracts were effective in the reduction of the incidence of all seed-borne fungi compared with untreated control seeds, this result indicate that the plant extracts of Zingiber officinale (Ginger), Moringer oleifera and Chromolena odorata probably have some fungicidal properties that inhibited the incidence of the seed-borne fungi. The $100 \%$ extracts of all the leaf extracts of Moringa oleifera, ginger and Chromolena Odorata were more effective in reducing the incidence of fungi than $80 \%, 60 \%$ and $20 \%$, respectively including the control experiment. This is an indication that dilution of the extracts reduced toxic effects of the plant extracts on the seed-borne fungi. This result agrees with the finding of Zaman et al (1997) that the efficacy of garlic, neem, ginger and onion extracts on seed-borne fungi of mustard declined with increased dilution.

This result equally agrees with that of Nwachukwu and Umechuruba (1997) that the efficacy of neem, basil, bitter-leaf, pawpaw and lemon grass on seed-borne fungi of African yam bean seeds declined with increasing dilution. The extracts were not phytotoxic to cowpea seeds; rather they improved seed germination more than the untreated control seeds. The ability of the extracts to increase seed germination could be attributed to the suppression of the incidence of the seed-borne fungi that could have killed the embryo of the seeds. This result is consistent with that of Parimelazhagen and Francis (1999) that established that leaf extracts of $C$. viscosum increased seed germination and improved seedling development of rice seeds. This present study has therefore shown that plant extracts of Moringa oleifera, Zingiber officinale and Chromolena odorata can be used as fungicidal seed treatment for the control of seed-borne fungi of cowpea seeds and for increasing seed germination.

\section{Conclusion}

The result of this study shows that plant extracts are effective in controlling seed-borne fungi of cowpea seeds. They are not phytoxic to the cowpea seed because they increase germination. The extracts have some fungicidal properties that inhibit the seed-borne fungi. In all, this plant extracts have no side effects compared to fungicides and are less expensive. Therefore they can be recommended as a measure for controlling seed-borne fungi of cowpea seed and increasing seed germination.

\section{References}

[1]. Agarwal, V. K. (1981). Seed-borne Fungi and Viruses of some important crops, University Press Pantnager, India, 64-67

[2]. Barnett, H.L. and Hunter, B.B. (1972). Illustrated Genera of Imperfecti Fungi $3{ }^{\text {rd }}$ Edition, Minnesota Burgoss Pub. Co, 1-25

[3]. Dixon, G.R.A. (1981). Vegetable crop diseases, Macmillian, Bagingstoke, 296-303

[4]. Emebiri, L. and Obisesan, I.O. (1988). Combining ability analysis in Cowpea yield and associated characters, Nigerian Journal of Genetics 7, 17-25.

[5]. (ISTA) International seeds testing Association (1966). International rules for seed test. Proc. Int. Seed Test Assoc. 31: 1-152

[6]. Kay, D.E. (1979). Food legumes, Tropical products Institutes, Lodon, 94, 232-235.

[7]. Kranz, J., Schumulterer, H. and Koch, W. (1977). Diseases, pests and weeds in tropical crops, John Wiley and Son Chichester, 148- 209.

[8]. Messiaen, C.M. and Lafon, R. (1970). Les Maladies des plantes Marcheres, Institute National de la Recherche Agronomique, Paris 397-400.

[9]. Nidiry, E.S.J.(1999). Antifungal activity of Tomato seed extracts, Fitoerapia 70 (2): 181-183.

[10]. Nwachukwu, E.O. and Umechuruba, C.I. (1997). Changes in Nutritional value of Africa yam bean seeds due to seed borne Fungi, Global Journal of Pure and Applied Science (2), 141-147.

[11]. Nwachukwu, E.O. and Umechuruba, C.I. (2001). Antifungal activities of some leaf extract on seed borne Fungi of African yam bean seeds, Seed germination and seedlings emergence, Journal of Applied Science and Environmental Management (2), 29-32.

[12]. Parmelazhagan, T. and Francis, K. (1999). Antifungal activity of cLerodendum Visvosum against Curvularia Lunata in rice seeds Journal of Mycology and plant pathology 29 (1): 139-141.

[13]. Purseglove, J.W. (1987). Tropical crops dicotyledons, Longman, Scientific and Technical, U.K.321-328.

[14]. Richardson, M.J. (1990). An annoted list of seed-borne disease. Fourth Edition. The International seed testing Association. 23-34.

[15]. Shah, N.H., Khan, M.I. and Azam, M.F. (1992). Seed and microflora of Cowpea and its control with extracts of Argemone Mexicana Bioved 3 (2), 168-176.

[16]. Singh, B.B., Mohon, D.R., Dashiell, K.E. and Jackai, L.E.N. (1999). Advances in Cowpea Research, International Institute of Tropical Agriculture, Ibadan, Nigeria, $375-340$.

[17]. Smart, J. (1976). Tropical pulses, Longman Harlow, 255-259.

[18]. Thiribhuvonamela, G. and Narasimba, V. (1998). Efficiency of plant extract on seed-borne pathogens of Sunflower, Madras Agricultural Journal 85 (516): 227-230.

[19]. Zaman, M.A., Saleh, A.K.M., Rahman, G.M.N., and Islam, M.T. (1997). Seed-borne Fungi of Mustard and their control with indigenous plant extracts, Bangladesh, Journal Plant of Pathology. 13 (2): 45-56. 